\title{
Phytoprotection
}

\section{A note on resistance to Hessian fly (Mayetiola destructor) [Diptera : Cecidomyidae] biotype $L$ in tribe Triticeae}

\author{
H.C. Sharma, J.E. Foster, H.W. Ohm et F.L. Patterson
}

Volume 73, numéro 2, 1992

URI : https://id.erudit.org/iderudit/706023ar

DOI : https://doi.org/10.7202/706023ar

Aller au sommaire du numéro

\section{Éditeur(s)}

Société de protection des plantes du Québec (SPPQ)l

\section{ISSN}

0031-9511 (imprimé)

1710-1603 (numérique)

Découvrir la revue

\section{Citer cet article}

Sharma, H., Foster, J., Ohm, H. \& Patterson, F. (1992). A note on resistance to Hessian fly (Mayetiola destructor) [Diptera : Cecidomyidae] biotype L in tribe Triticeae. Phytoprotection, 73(2), 79-82. https://doi.org/10.7202/706023ar
Résumé de l'article

Quarante et une accessions de blés primitifs et indigènes (Triticum spp.), 16 accessions du genre Aegilops et 20 accessions ou cultivars du genre Agropyron ont été évaluées pour la première fois pour leur réaction au biotype $L$ de la mouche de Hesse (Mayetiola destructor). Trois accessions du Triticum monococcum, 13 accessions du genre Aegilops et 13 accessions ou cultivars du genre Agropyron ont été trouvées résistantes de façon homogène. L'antibiose s'est manifestée dans certains cas mais dans certains autres, il est apparu une résistance physique attribuable à la présence de la pubescence foliaire ou de la ligule. La pubescence du Triticum boeoticum n'a pas été efficace afin de procurer de la résistance. 


\title{
A note on resistance to Hessian fly (Mayetiola destructor) [Diptera: Cecidomyidae] biotype $L$ in tribe Triticeae
}

\author{
H. C. Sharma' ${ }^{1}$ J. E. Foster ${ }^{1,2}$, H. W. Ohm¹, and F. L. Patterson ${ }^{1}$
}

Received 1992-02-19; accepted 1992-07-24

Forty-one accessions of primitive and wild wheats (Triticum species), 16 accessions of Aegilops species, and 20 accessions or cultivars of Agropyron species were evaluated for the first time for reaction to biotype $L$ of Hessian fly (Mayetiola destructor). Three accessions of Triticum monococcum, 13 accessions of Aegilops species, and 13 accessions or cultivars of Agropyron species were found homogeneously resistant. Antibiosis was operative in some cases but in others there appeared to be physical resistance due to the presence of leaf pubescence or ligule. Pubescence of Triticum boeoticum was not effective in providing resistance.

Sharma, H. C., J. E. Foster, H. W. Ohm, and F. L. Patterson. 1992. A note on resistance to Hessian fly (Mayetiola destructor) [Diptera: Cecidomyidae] biotype L in tribe Triticeae. PHYTOPROTECTION 73: 79-82.

Quarante et une accessions de blés primitifs et indigènes (Triticum spp.), 16 accessions du genre Aegilops et 20 accessions ou cultivars du genre Agropyron ont été évaluées pour la première fois pour leur réaction au biotype $L$ de la mouche de Hesse (Mayetiola destructor). Trois accessions du Triticum monococcum, 13 accessions du genre Aegilops et 13 accessions ou cultivars du genre Agropyron ont été trouvées résistantes de façon homogène. L'antibiose s'est manifestée dans certains cas mais dans certains autres, il est apparu une résistance physique attribuable à la présence de la pubescence foliaire ou de la ligule. La pubescence du Triticum boeoticum n'a pas été efficace afin de procurer de la résistance.

Hessian fly (Mayetiola destructor Say)[Diptera: Cecidomyiidae], an obligate parasite of grasses of the tribe Triticeae is a serious pest of wheat (Triticum aestivum L.) in North America and many other countries (Maxwell and Jennings 1980). The larvae feed at the base of the leaf sheath and damage wheat by stunting. Of the 13 biotypes, biotype GP is the least and biotype $L$ is the most virulent (Gallun 1977; Sosa 1981). Twenty genes have been identified in Triticum aestivum, Triticum turgidum var. durum Desf. and Aegilops

1. Dept. of Agronomy, USDA-ARS, Purdue University, W. Lafayette, Indiana

2. Present address: Dept. of Entomology,

University of Nebraska, Lincoln, Nebraska squarrosa L. that confer resistance against different biotypes of the fly, but some of the resistance has been overcome by new virulent biotypes (Amri etal. 1990; Obanni et al. 1989). Thus, new sources of resistance must be sought continuously in domesticated wheats as well as in their related species.

Hatchett and Gill (1983) and Gill et al. (1986) reported resistance in Aegilops species to biotype D of Hessian fly. Gill et al. (1983) screened wild wheats Triticum boeoticum Boiss em. Schiem., Triticum timopheevii var. araraticum Jakubzn. and Triticum turgidum var. dicoccoides Schrank, and found resistance to biotype $D$ in some accessions. Friebe et al. (1990) reported resistance to biotype $L$ in a 
hexaploid wheat with a wheat-rye translocation. We report, for the first time, on the results of screening of primitive and wild wheats (Triticum species), Aegilops species, and Agropyron species for resistance to biotype $\mathrm{L}$.

Forty-one accessions of primitive and wild wheats, 16 accessions of Aegilops species, and 17 accessions and three cultivars of Agropyron species (Table 1) were screened for reaction to biotype $L$ of Hessian fly.

Seeds were planted in $54 \mathrm{~cm} \times 36 \mathrm{~cm} \times$ $8 \mathrm{~cm}$ wooden flats filled with prepared greenhouse soil mixture. There were 12 equidistant rows widthwise in each flat. Twenty-five to thirty seeds were planted in each row. Common wheat cultivars Seneca and Abe were included as susceptible controls in each of the 12 flats used in this study. The number of plants of each accession varied from 6 to 60 depending on the number of seeds available and their germination rate. The methods of infestation and evaluation were similar to those described by Cartwright and Lahue (1944). Seedlings were infested at oneleaf stage in a growth chamber $\left(19^{\circ} \mathrm{C}, 12 \mathrm{~h}\right.$ photoperiod, high humidity). Plant reactions to larval feeding were determined 3 wk later. Plants that were stunted and dark green were classified as susceptible, and the plants that were yellowish green and not stunted were classified as resistant. Plants of the resistant accessions were examined for the presence of egg cases on the leaf blade and for larvae at the base of the leaf sheath. Similarly, susceptible plants were examined for live larvae at the base of the leaf sheath. Some of the resistant accessions were progenytested in which seeds produced by the tested plants on self-pollination were planted and screened for reaction to biotype L to confirm homozygosity. Observations were also made on the presence or absence of leaf pubescence, the ligule and auricles.

The controls were uniformly susceptible in all flats. Of the 41 accessions of primitive and wild wheats, three were homogeneously resistant, while others were either homogeneously susceptible or heterogeneous (Table 1). The three resistant accessions were 'G1471', 'PI191146' (G1560) and 'PI221415' (G3304) of the primitive diploid Triticum monococcum L. Of the 25 progeny plants of 'G1471' and 42 of 'PI221415', only one plant in 'PI221415' was susceptible. Egg cases found on leaf and dead larvae observed at the base of leaf sheath indicated that the mechanism of resistance was antibiosis (Gallun 1977). It may be added that no progeny test was performed on G1560 and as such resistance reaction of this accession should be considered preliminary.

Thirteen of the 16 accessions of the Aegilops species were resistant and three accessions of Aegilops squarrosa had both resistant and susceptible seedlings (Table 1). When progenies of five of the seven resistant accessions of Aegilops squarrosa, and progenies of Aegilops speltoides Tausch, and Aegilops caudata L. were tested, all were homozygous resistant. In the case of the progeny of accession 'G3395' of Aegilops squarrosa, egg cases and dead larvae were observed; thus, antibiosis was the basis of resistance (Gallun 1977). In three accessions of $A e$ gilops squarrosa, and one each of Aegilops speltoides, Aegilops caudata, and Aegilops kotschyiBoiss. examined, egg cases, dead eggs or dead larvae were present on leaf blade but no dead larvae were found at the base of leaf sheath. The leaves in these accessions were pubescent and liguled, and the resistance observed could be due to non-preference. Roberts et al. (1979) observed that the number of Hessian fly eggs that hatched and developed into puparia was lower on pubescentleaved than on glabrous-leaved wheat. Of the seven accessions of Aegilops squarrosa found resistant to biotype $L$ in the present study, five were resistant to biotype D also (Gill et al. 1986). Therefore, resistance in these accessions does not appear to be biotype specific.

Of the 20 accessions or cultivars of Agropyron species tested, 13 were homogeneously resistant, 1 was homogeneously susceptible, and 6 were heterogeneous (Table 1). In the resistant collection of Agropyron intermedium (Host) Beauv. from South Dakota, dead larvae were found behind the leaf sheath indicating antibiosis. In Agropyron trichophorum (Link) Richter cv. Luna, which has densely pubescert leaves, and in Agro- 
pyron intermedium cv. Oahe, which has sparsely pubescent leaves with hairy ligules, dead eggs were present on leaf blades but no dead larvae were found at the leaf base. The same was true in the progeny test of Oahe. The leaf pubescence may have caused desiccation of eggs or hairy ligules may have hindered larva migration.

Isolation of homozygous resistant and homozygous susceptible accessions of Triticum monococcum provided the basis for a genetic study of resistance to biotype
L at the diploid level. Resistant accessions of Triticum monococcum identified represent potentially new sources of genetic variation. Genes from Triticum monococcum have been transferred to common wheat by natural recombination in appropriate hybrids because Triticum monococcum has one of the three genomes of common wheat (Kerber and Dyck 1973). The expression of transferred genes may sometimes (Dyck and Kerber 1985; Valkoun et al. 1986), but not always (Mclntosh et al. 1984), suffer from "dilution effect". Likewise Aegilops squarrosa

Table 1. Reaction of Triticum (T.) species, Aegilops (Ae.) species, and Agropyron (A.) species to Hessian fly biotype $\mathrm{L}$

\begin{tabular}{|c|c|c|c|c|}
\hline \multirow[b]{2}{*}{ Species } & \multirow[b]{2}{*}{$\begin{array}{l}\text { Number of } \\
\text { accessions or } \\
\text { ultivars tested }\end{array}$} & \multicolumn{3}{|c|}{$\begin{array}{l}\text { Number of accessions found } \\
\text { within each type of reaction }\end{array}$} \\
\hline & & $\begin{array}{l}\text { Homogeneously } \\
\text { resistant }\end{array}$ & $\begin{array}{l}\text { Homogeneously } \\
\text { susceptible }\end{array}$ & Heterogeneous \\
\hline T. monococcum & 21 & 3 & 9 & 9 \\
\hline T. boeoticum & 9 & 0 & 2 & 7 \\
\hline T. urartu & 8 & 0 & 5 & 3 \\
\hline T. dicoccoides & 2 & 0 & 1 & 1 \\
\hline T. araraticum & 1 & 0 & 0 & 1 \\
\hline Ae. squarrosa & 10 & 7 & 0 & 3 \\
\hline Ae. longissima & 1 & 1 & 0 & 0 \\
\hline Ae. speltoides & 1 & 1 & 0 & 0 \\
\hline Ae. caudata & 1 & 1 & 0 & 0 \\
\hline Ae. kotschyi & 1 & 1 & 0 & 0 \\
\hline Ae. ventricosa & 1 & 1 & 0 & 0 \\
\hline Ae. cylindrica & 1 & 1 & 0 & 0 \\
\hline A. intermedium & 2 & 2 & 0 & 0 \\
\hline \multirow{2}{*}{ A. elongatum } & 1 & 1 & 0 & 0 \\
\hline & 1 & 0 & 0 & 1 \\
\hline A. trichophorum & 1 & 0 & 0 & 1 \\
\hline A. junceum & 6 & 5 & 0 & 1 \\
\hline A. yezoense & 1 & 1 & 0 & 0 \\
\hline A. trachycaulum & 2 & 0 & 0 & 2 \\
\hline A. ciliare & 1 & 0 & 0 & 1 \\
\hline A. campestre & 1 & 1 & 0 & 0 \\
\hline A. batalini & 1 & 1 & 0 & 0 \\
\hline A. nodosum & 1 & 1 & 0 & 0 \\
\hline A. stipifolium & 1 & 1 & 0 & 0 \\
\hline A. caespitosum & 1 & 0 & 1 & 0 \\
\hline
\end{tabular}

a One diploid and one decaploid. 
is the donor of the $D$ genome to common wheat and transfer of resistance of G3395 into wheat should be possible. However, the transfer of resistance from Agropyron into wheat will require specialized techniques because of non-homology of the chromosomes.

Although leaves of Triticum boeoticum were pubescent, no resistant accessions were found in this species. The pubescence in Triticum boeoticum was not sparser or shorter than in resistant Aegilops or Agropyron species. It may be speculated that the type of pubescence in Triticum boeoticum accessions differs from that of the Aegilops and Agropyron accessions tested. Lemke and Mutschler (1984) observed that different trichome types may impart different protection levels from insects.

\section{ACKNOWLEDGEMENTS}

We acknowledge the help of Greg Safranski and Sue Cambron for Hessian fly testing. We also thank J. G. Waines, B. S. Gill, D. R. Dewey, and R. H. Shukle for the seed. Purdue Univ. Agric. Exp. Stn. Journal No. 12505. The research was supported in part by Purdue Univ. Agric. Exp. Stn., and Public Varieties of Indiana.

\section{REFERENCES}

Amri, A., T.S. Cox, B.S. Gill, and J.H. Hatchett. 1990. Chromosomal location of the Hessian fly resistance gene $\mathrm{H} 20$ in 'Jori' durum wheat. J. Hered. 81: 71-72.

Cartwright, W.B., and D.W. Lahue. 1944. Testing wheat in the greenhouse for Hessian fly resistance. J. Econ. Entomol. 37: 385387.

Dyck, P.L., and E.R. Kerber. 1985. Resistance of the race specific type. Pages 469-500 in A.P. Roelfs, and W.R. Bushnell (eds.), The cereal rusts vol. II: Diseases, distribution, epidemiology and control. Academic Press, Orlando, Florida.

Friebe, B., J.H. Hatchett, R.G. Sears, and B.S. Gill. 1990. Transfer of Hessian fly resistance from 'Chaupon' rye to hexaploid wheat via a $2 B S / 2 R L$ wheat-rye chromosome translocation. Theor. Appl. Genet. 79: 385389.

Gallun, R.L. 1977. Genetic basis of Hessian fly epidemics. Ann. N. Y. Acad. Sci. 287: 223229.
Gill, B.S., L.E. Browder, J.H. Hatchett, T.L. Harvey, T.J. Martin, W.J. Raupp, H.C. Sharma, and J.G. Waines. 1983. Disease and insect resistance in wild wheats. Proc. 6th Int. Wheat Genet. Symp., Kyoto, Japan. p. 785-792.

Gill, B.S., W.J. Raupp, H.C. Sharma, L.E. Browder, J.H. Hatchett, T.L. Harvev, and J.G. Moseman. 1986. Resistance in Aegilops squarrosa to wheat leaf rust, wheat powdery mildew, greenbug and Hessian fly. Plant Dis. 70: 553-556.

Hatchett, J.H., and B.S. Gill. 1983. Expression and genetics of resistance to Hessian fly in Triticum tauschii (Coss) Schmal. Proc. 6th Int. Wheat Genet. Symp., Kyoto, Japan. p. 807-811.

Kerber, E.R., and P.L. Dyck. 1973. Inheritance of stem rust resistance transferred from diploid wheat (Triticum monococcum) to tetraploid and hexaploid wheat and chromosome location of the gene involved. Can. J. Genet. Cytol. 15: 397-409.

Lemke, C.A., and M.A. Mutschler. 1984. Inheritance of glandular trichomes in crosses between Lycopersicon esculentum and $L$. pennellii. J. Amer. Soc. Hortic. Sci. 109: 592-596.

Maxwell, F.G., and P.R. Jennings. 1980. Breeding plants resistant to insects. John Wiley \& Sons, $683 \mathrm{pp}$.

Mclntosh, R.A., P.L. Dyck, T.T. The, J. Cusick, and D.L. Milne. 1984. Cytogenetical studies in wheat XIII: Sr 35 - a third gene from Triticum monococcum for resistance to Puccinia graminis tritici. Z. Pflanzenzüchtg. 92: 1-14.

Obanni, M., H.W. Ohm, J.E. Foster, and F.L. Patterson. 1989. Reactions of elever tetraploid and hexaploid wheat introductions to the Hessian fly. Crop Sci. 29: 267-269.

Roberts, J.J., R.L. Gallun, F.L. Patterson, and J.E. Foster. 1979. Effects of wheat leaf pubescence on the Hessian fly. J. Econ. Entomol. 72: 211-214.

Sosa, O., Jr. 1981. Biotype L, ninth biotype of the Hessian fly. J. Econ. Entomol. 71 : 458460.

Valkoun, J., D. Kucerova, and P. Bartos. 1986. Transfer of leaf rust resistance from Triticum monococcum L. to hexaploid wheat. $\mathrm{Z}$. Pflanzenzüchtg. 96: 271-278. 